\title{
REVIEW OF THE RECORDS OF THE SMALLTOOTH SAND TIGER SHARK, ODONTASPIS FEROX (ELASMOBRANCHII: LAMNIFORMES: ODONTASPIDIDAE), IN THE AZORES
}

\author{
Luís M.D. Barcelos ${ }^{1,2 *}$, José M.N. Azevedo ${ }^{1,3}$, Jürgen Pollerspöck ${ }^{4}$, and João P. Barreiros ${ }^{1,2}$ \\ ${ }^{1}$ Centre for Ecology, Evolution, and Environmental Changes, Azorean Biodiversity Group, Angra do Heroísmo, \\ Portugal \\ ${ }^{2}$ Faculty of Agricultural and Environmental Sciences, University of the Azores, Angra do Heroismo, Portugal \\ ${ }^{3}$ Faculty of Sciences and Technology, University of the Azores, Ponta Delgada, Portugal \\ ${ }^{4}$ Bavarian State Collection of Zoology, Munich, Germany
}

\begin{abstract}
Barcelos L.M.D., Azevedo J.M.N., Pollerspöck J., Barreiros J.P. 2018. Review of the records of the smalltooth sand tiger shark, Odontaspis ferox (Elasmobranchii: Lamniformes: Odontaspididae), in the Azores. Acta Ichthyol. Piscat. 48 (2): 189-194.
\end{abstract}

\begin{abstract}
In recent years Azorean fishermen reported the presence of the smalltooth sand tiger shark, Odontaspis ferox (Risso, 1810), a very rare demersal shark species, associated with insular shelves and slopes, with occasional incursions into shallow waters and of poorly known biology and ecology. There are fourteen new records of this species, between 1996 and 2014, captured by spearfishing, harpoons, hand lines, or entangled in fishing gear in the Azores. These records were analysed and complemented with fishermen interviews, providing new locations and new biological data for this species. Also, specimens photographs were studied and post-mortem analysis were carefully carried out in one individual.

This species is rare and captured only as bycatch in shallow waters. More detailed information on this species is critically needed in order to assess its conservation status and implement management guidelines. Bycatch statistics are crucial in this respect.
\end{abstract}

Keywords: new records, smalltooth sand tiger shark, Odontaspis ferox, Azores, North-eastern Atlantic

\section{INTRODUCTION}

The lamniform Odontaspis ferox (Risso, 1810) is a large shark, with a short-pointed snout, small eyes, protruding spike-like, characteristic multicuspid teeth (Fig. 1), a tearing-type dentition, and small dorsal and anal fins which are similar in size; the two dorsal fins being sub-equal, constitute also an important diagnose feature of odontaspid sharks (Compagno et al. 1989). This species inhabits warm-temperate and tropical seas, on or near the bottom on continental and insular shelves and upper slopes at depths ranging from 13 to $420 \mathrm{~m}$ while it is also possibly epipelagic from 140 to $180 \mathrm{~m}$ over the ocean floor (Compagno 2002, Barreiros and Gadig 2011), with a maximal depth range of $880 \mathrm{~m}$ (Graham et al. 2016). This species was first described from the Mediterranean Sea by Risso (1810), its last confirmed record from the North African Mediterranean area (Tunisia) dates back to the mid 1770s. (Capapé 1975). Fergusson et al. (2008) summarized the vast geographic and depth distribution of this species with more than 160 records. Albeit this wide range, the species seems to be naturally rare with fragmented populations (Graham et al. 2016).

Analogous to the current distribution of Odontaspis ferox, reports of fossil shark teeth of this species are rare and poorly documented in the scientific literature (Cappetta 2012). Since 2000 only six publications described new records of $O$. ferox: Atlantic Miocene, North Carolina, Purdy et al. (2001); Venezuela, Aguilera and Rodrigues de Aguilera (2001); Italy, Pliocene, Marsili (2006), Fulgosi et al. (2009); Pacific Miocene, Chile, Suarez et al. (2006), Staig et al. (2015). On the other hand, there are no fossil records of Odontaspis noronhai (Maul, 1955). By contrast, fossil teeth of Carcharias taurus Rafinesque, 1810 are common and widespread (Cappetta 2012).

It is notable that the fossil records of $O$. ferox are limited to sediments close to the mainland (Purdy et al. 2001, Aguilera and Rodrigues de Aguilera 2001) and no fossil records from the Atlantic islands are known so far

"Correspondence: Dr Luis M.D. Barcelos, CE3C - Centre for Ecology, Evolution and Environmental Changes, Azorean Biodiversity Group, University of the Azores, Rua Capitão João D’Ávila, 9700-042 Angra do Heroísmo, Portugal, phone: (+351) 295 402 200, e-mail: (LMDB) ldbarcelos@gmail.com, (JMNA) jose.mv.azevedo@uac.pt, (JP) juergen.pollerspoeck@gmail.com, (JPB)joao.ps.barreiros@uac.pt. 


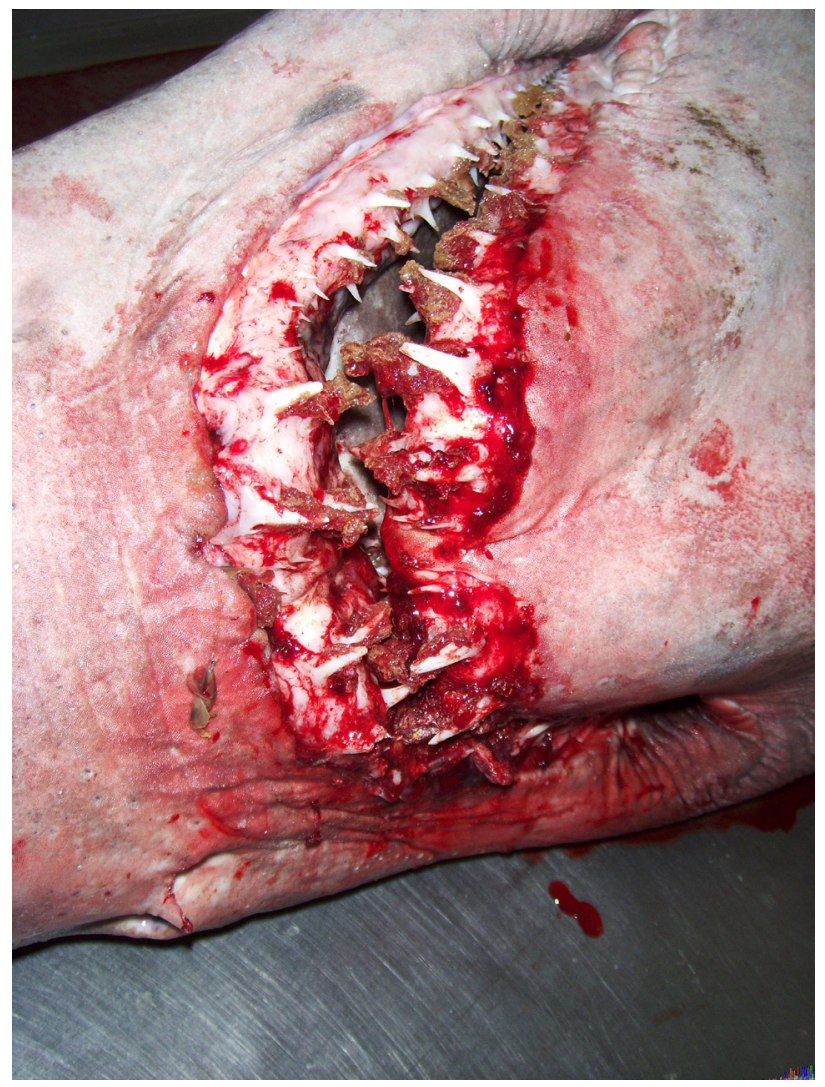

Fig. 1. Details of the characteristic multicuspid teeth of the Odontaspis ferox, a specimen from Terceira Island (captured on the 28 June 2013)

[Azores: Ávila et al. (2012); Canary Islands: Meco et al. (2015), Betancort et al. (2016); Cape Verde Islands: Serralheiro (1976); Antilles - Carriacou Island: Portell et al. (2008); Cuba: Iturralde-Vinent et al. (1996)]. Despite this fact, Neogene marine sediments are known from the Azores (Ávila et al. 2012).

In addition, fishes of the genus Odontaspis are completely absent in the Tethys/Paratethys/Mediterranean Sea during the Miocene (Cappetta 2012) and the oldest fossil record from the Mediterranean is from the Lower Pliocene (Zanclean, 5.333 MY) (Marsili 2006, Fulgosi et al. 2009). These sediments settled after the Messinian salinity crisis (Marsili 2008), indicating that O. ferox probably migrated to the Mediterranean Sea during Zanclean for the very first time.

This species was first reported to occur in the Azores based on the results of the historic oceanographic campaigns lead by King Carlos I of Portugal and Prince Albert I of Monaco during the last decade of the 19th century (de Monaco 1889, Bragança 1902). After a gap of about 100 years, the species was again recorded by Santos et al. (1997) and Anonymous (2017), based on four specimens captured in 1991 and 1994 (see Santos et al. 1997 for detailed information).

Little is known about the reproduction of O. ferox. To this point, no pregnant females have been reported on the scientific literature (Ferguson et al. 2008, Graham et al. 2016). Only one adult female has been described with hundreds of small eggs (diameter about $3 \mathrm{~mm}$ ) in its right ovary (Villavicencio-Garayzar 1996). Compagno (2002) suspected that $O$. ferox practices uterine cannibalism in the form of oophagy. This form of oophagy has been hitherto documented only for Carcharias taurus (see Musick and Ellis 2005) while Saïdi et al. (2005) commented general oophagy in sharks on their analysis of a pregnant Carcharodon carcharias (Linnaeus, 1758).

The very low reproductive capacity associated with the natural rareness makes the species highly susceptible to exploitation, mainly in the form of fisheries by-catch. For this reason, it is considered Vulnerable by the IUCN Red List (Graham et al. 2016).

In this paper we report 14 recently captured specimens and the circumstances involving their capture, providing data that will lead to a better understanding of the occurrence and status of this species.

\section{MATERIAL AND METHODS}

Between 23 March 1996 and 2 July 2014 fourteen specimens of Odontaspis ferox were captured off the Azorean islands of Flores, Pico, Graciosa, Terceira, São Miguel, and Santa Maria (Fig. 2), entangled in fishing gear or captured otherwise by spearfishing, harpoons, or hand lines. The available data and photographs (because of low resolution cannot be published) were collected (Table 1) and studied, although only the 28 June 2013 specimen from Terceira reached one of us (JPB) and could be fully analysed, including the preservation of the head now deposited frozen in the Anatomy Laboratory of the Faculty of Agrarian and Environmental Sciences, Azores University. Species determination followed Hennemann (2001) and Barreiros and Gadig (2011). We also looked extensively for any additional possible records of this species in the Azores.

Additionally, 35 fishermen from the São Mateus fishing port (south coast of Terceira Island) were interviewed and shown photos and drawings of $O$. ferox in order to verify if they were familiarized or even knew this species of shark.

\section{RESULTS}

Judging by the size at maturity (estimated by Fergusson et al. 2008), the six captured males of Odontaspis ferox were adults, with one of them exceeding the maximum size reported by the above-mentioned researchers (see their table I). Five of the females (including the two that were captured in the same fishing gear) were sub-adults. All specimens were captured in shallow waters from $0 \mathrm{~m}$ (stranded) to $50 \mathrm{~m}$ of depth.

Azorean fishermen commonly report catching a "different Albafar" or an "...abnormal Albafar" occasionally caught by deep longline trawls, (several pers. comm. to JPB since 1994 mainly from the fishing port of São Mateus) with two dorsal fins and always point out that it is $O$. ferox when shown a photo of this shark. "Albafar" is the common name used locally for Hexanchus griseus (Bonnaterre, 1788), a species familiar to and feared by local fishermen. 


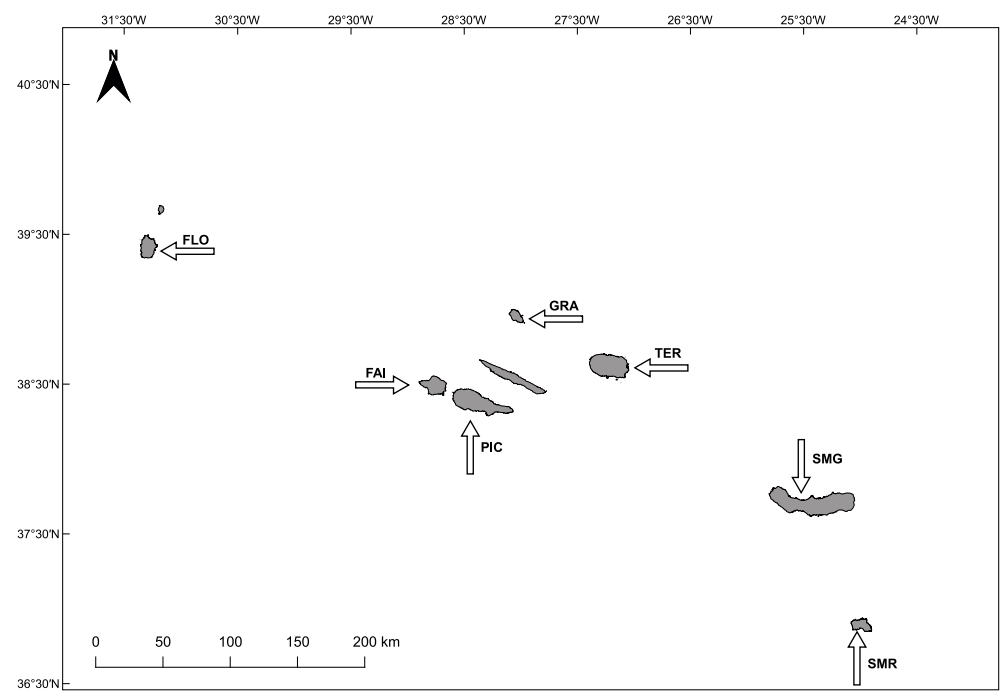

Fig. 2. Location of Azores archipelago, with indication of the islands where the specimens where caught: FAI = Faial Island, PIC $=$ Pico Island, GRA $=$ Graciosa Island, $\mathrm{TER}=$ Terceira Island, $\mathrm{SMG}=$ São Miguel Island, $\mathrm{SMR}=\mathrm{Santa}$ Maria Island

Table 1

Recent records of Odontaspis ferox for the Azores with reference to date, locations, sex, sizes, capture methods, photos and other observations

\begin{tabular}{|c|c|c|c|c|c|c|c|c|c|}
\hline Date & Island & Location & $n$ & Sex & $\mathrm{TL}[\mathrm{cm}]$ & Capture method & Depth $[\mathrm{m}]$ & Photos & Reference or comment \\
\hline 12 Dec1991 & FAI & & 1 & $\mathrm{M}$ & 280 & & & & Santos et al. 1997 \\
\hline 20 Mar1994 & GRA & & 3 & M & $152-304$ & Gillnets & & & Santos et al. 1997 \\
\hline 23 Mar 1996 & SMG & São Roque beach & 1 & $\mathrm{~F}$ & 398 & Stranded & 0 & + & $\begin{array}{l}\text { Stranded, unknown } \\
\text { cause of death }\end{array}$ \\
\hline 25 Apr 1996 & SMG & Lagoa harbour & 1 & M & 300 & Stranded & 0 & + & $\begin{array}{l}\text { Collected dead in the } \\
\text { harbour; some bleeding } \\
\text { from the claspers }\end{array}$ \\
\hline 01Jan 2004 & PIC & & 1 & M & $>250$ & & & + & \\
\hline 08 Jun 2005 & PIC & & 1 & M & ca. 200 & & & + & \\
\hline 2006 & SMG & $\begin{array}{l}\text { Vila Franca do } \\
\text { Campo }\end{array}$ & 1 & & & & & + & \\
\hline 22 Mar 2007 & SMR & & 1 & $\mathrm{~F}$ & ca. 300 & & & + & \\
\hline 17 Jun 2009 & SMR & & 1 & $\mathrm{~F}$ & ca. 200 & & & + & \\
\hline $23 \mathrm{Jul} 2011$ & FLO & $\begin{array}{l}\text { Off the Maria } \\
\text { Vaz Islet }\end{array}$ & 1 & M & 368 & Spearfishing & $<20$ & + & \\
\hline 19 Jul 2012 & SMG & Rabo de Peixe & 1 & M & ca. 200 & Spears and hooks & $<10$ & & Captured in the harbour \\
\hline 05 Jun 2013 & SMG & $\begin{array}{l}\text { Povoação } \\
\text { Harbour }\end{array}$ & 1 & M & ca. 200 & Spears and hooks & $<5$ & + & Captured in the harbour \\
\hline 28 Jun 2013 & TER & & 1 & $\mathrm{~F}$ & 357 & & & + & \\
\hline 13 May 2014 & PIC & & 1 & $\mathrm{~F}$ & ca. 300 & & & + & \\
\hline 02 Jul 2014 & GRA & Folga harbour & 2 & $\mathrm{~F}$ & $250-300$ & Inshore gillnets & $<30$ & + & Caught on the same line \\
\hline
\end{tabular}

$n=$ number of specimens studied, $\mathrm{TL}=$ total length; FAI $=$ Faial Island, $\mathrm{GRA}=$ Graciosa Island, $\mathrm{PIC}=$ Pico Island, TER $=$ Terceira Island, SMG = São Miguel Island, SMR = Santa Maria Island.

\section{DISCUSSION}

The number of documented records of Odontaspis ferox at the Azores since 1991 reached a total of eighteen, including the 14 new records reported herewith. In no other area of the North-eastern Atlantic has such a number of individuals been detected, especially in a geographically restricted zone like the Azores where Porteiro et al. (2010) referred to this species as a vagrant. These findings suggest that this species predominantly occurs along the Mid-Atlantic Ridge associated with warm temperate and tropical seas of insular shelves and upper slopes.

The presently reported observations confirm the assessment of Graham et al. (2016) that this species is rare and captured only as a bycatch. In the Azores, bottom trawls (the main sources of bycatch and responsible for generating large amounts of discards) are not used, but instead, there is a heavy deep-water 
fishing, using demersal longlines. It must also be noted that both specimens of $O$. ferox, which were available for examination by Naylor et al. (2012a, 2012b), were collected from the Azores.

The demersal habits of $O$. ferox are reflected in the absence of any records of bycatch on pelagic fisheries. In fact, an extensive review of bycatch in drift nets in the NE Atlantic (Rogan and Mackey 2007) does not record this species. The same was also noted for the pelagic longline fishery (Coelho et al. 2012).

Odontaspis ferox has also been captured in shallow waters. Gillnets used in the Azores represent a shallow water gear deployed at depths no greater than $30 \mathrm{~m}$. Two males have been captured with this method in the 1990s. More recently, a large female was captured inside a fishing harbour. Divers in the Canary Islands have also registered and documented on video the recurring presence of females (said to be pregnant) in summer and autumn on shallow waters around El Hierro Island, on the Canary Islands (A. Pinilla, personal communication). After the records published by Fergusson et al. (2008), several others have come to light (Table 2) that confirm the species' global distribution as well as its local rareness.

As the EU member states prepare to implement the discard ban imposed by the Common Fisheries Policy, it is expected that more information on this and other similarly poorly know species will accumulate. This can be an opportunity to implement conservation actions directed at poorly known deep-water sharks such as Odontaspis ferox.

Table 2

Records of Odontaspis ferox after 2008 (supplementing records listed by Fergusson et al. 2008)

\begin{tabular}{ll}
\hline Locality & Reference \\
\hline Fortaleza, Brazil & Santander-Neto et al. 2011 \\
Costa Rica & Cortés et al. 2012 \\
Galapagos Island & Acuña-Marrero et al. 2013, Ritter \\
& and Compagno 2013 \\
Taiwan & Hsu et al. 2013 \\
Cape-Verde & Wirtz et al 2013 \\
Chile & Long et al. 2014 \\
Equador & Estupiñán-Montaño et al. 2016 \\
Australia & Wellington et al. 2017 \\
\hline
\end{tabular}

Fig. 2. Location of Azores archipelago, with indication of the islands where the specimens where caught: FAI $=$ Faial Island, PIC $=$ Pico Island, GRA $=$ Graciosa Island, TER $=$ Terceira Island, $\mathrm{SMG}=$ São Miguel Island, SMR = Santa Maria Island

\section{ACKNOWLEDGEMENTS}

The authors are thankful to João Brum and to all anonymous fishermen that collected the sharks and provided the relevant information.

\section{REFERENCES}

Acuña-Marrero D., Zimmerhackel J.S., Mayorga J., Hearn A. 2013. First record of three shark species, Odontaspis ferox, Mustelus albipinnis and Centrophorus squamosus, from the Galápagos Islands.
Marine Biodiversity Records 6: e87. DOI: 10.1017/ S1755267213000596

Aguilera O., Rodridues de Aguilera D. 2001. An exceptional coastal upwelling fish assemblage in the Caribbean Neogene. Journal of Paleontology 75 (3): 732-742. DOI: 10.1666/0022-3360(2001)075<0732:AECUFA $>$ 2.0.CO;2

Anonymous 2017. Odontaspis ferox (Risso, 1810). In: GBIF Backbone Taxonomy. Checklist Dataset [Accessed on 2 January 2018.] DOI: 10.15468/39omei

Ávila S.P., Ramalho R., Vullo R. 2012. Systematics, palaeoecology and palaeobiogeography of the Neogene fossil sharks from the Azores (Northeast Atlantic). Annales de Paléontologie 98 (3): 167-189. DOI: 10.1016/j.annpal.2012.04.001

Barreiros J., Gadig O. 2011. Sharks and rays from the Azores an illustrated catalogue. 1st edn. IAC - Instituto Açoriano de Cultura, Angra do Heroísmo, Portugal.

Betancort J., Lomoschitz A., Meco J. 2016. Los peces (Chondrichthyes, Osteichthyes) del Plioceno inferior de Gran Canaria y Fuerteventura (Islas Canarias, España). Estudios Geológicos 72 (2): 1-15. DOI: 10.3989/egeol.42380.399

Bragança C. 1902. Bulletin des campagnes scientifiques accomplies sur le yacht "Amelia" par D. Carlos de Bragança. Volume I. Imprimerie nationale, Lisbonne, Portugal.

Capapé C. 1975. Sélaciens nouveaux et rares le long des côtes tunisiennes. Premières observatuions biologiques. Archives de l'Institut Pasteur de Tunis 21 (1-2): 107-128.

Cappetta H. 2012. Volume 3E: Chondrichthyes; Mesozoic and Cenozoic Elasmobranchii: Teeth. In: Schultze H.-P. (ed.) Handbook of paleoichthyology. Verlag Dr. Friedrich Pfeil, München, Germany.

Coelho R., Fernandez-Carvalho J., Lino P.G., Santos M.N. 2012. An overview of the hooking mortality of elasmobranchs caught in a swordfish pelagic longline fishery in the Atlantic Ocean. Aquatic Living Resources 25 (4): 311-319. DOI: 10.1051/alr/2012030

Compagno L.J.V. 2002. Sharks of the World; an annotated and illustrated catalogue of shark species known to date. Volume 2. Bullhead, mackerel and carpet sharks (Heterodontiformes, Lamniformes and Orectolobiformes). FAO Species Catalogue for Fishery Purposes. FAO, Rome.

Compagno L.J.V., Ebert D.A., Smale M.J. 1989. Guide to the sharks and rays of southern Africa. New Holland Ltd., London, UK.

Cortés J., Sánchez-Jiménez A., Rodríguez-Arrieta J.A., Quirós-Berrantes G., González P.C., Blum S. 2012. Elasmobranchs observed in deepwaters (45-330 m) at Isla del Coco National Park, Costa Rica (Eastern Tropical Pacific). Revista de Biología Tropical 60 (Suppl. 3): 257-273.

de Monaco A. 1889. Recherche des animaux marins. Progrès réalisés sur l'Hirondelle dans l'outillage special. Pp. 133-189. In: Compte-rendu des séances du Congrès international de zoologie. Paris. 
Estupiñán-Montaño C., Galván-Magaña F., HacohenDomené A., Estupiñán-Ortíz J.F. 2016. First reports of smalltooth sand tiger sharks, Odontaspis ferox (Elasmobranchii: Lamniformes: Odontaspididae), off the continental Ecuador. Acta Ichthyologica et Piscatoria 46 (3): 251-253. DOI: 10.3750/ AIP2016.46.3.09

Fergusson I.K., Graham K.J., Compagno L.J.V. 2008. Distribution, abundance and biology of the smalltooth sandtiger shark Odontaspis ferox (Risso, 1810) (Lamniformes: Odontaspididae). Environmental Biology of Fishes 81 (2): 207-228. DOI: 10.1007/ s10641-007-9193-X

Fulgosi F., Casati S., Orlandini A., Persico D. 2009. A small fossil fish fauna, rich in Chlamydoselachus teeth, from the Late Pliocene of Tuscany (Siena, central Italy). Cainozoic Research 6 (1-2): 3-23.

Graham K.J., Pollard D.A., Gordon I., Williams S., Flaherty A.A., Fergusson I., Dicken M. 2016. Odontaspis ferox (errata version) 2016. The IUCN Red List of Threatened Species 2016: e.T41876A103433002. [Downloaded on 15 June 2018.] DOI: 10.2305/IUCN.UK.2016-1.RLTS. T41876A2957320.en

Hennemann R.M. 2001. Sharks and rays: Elasmobranch guide of the World. 1st edn. IKAN - Underwasserarchiv, Frankfurt, Germany.

Hsu H.H., Joung S.J., Ebert D.A., Lin C.Y. 2013. Records of new and rare elasmobranchs from Taiwan. Zootaxa 3752 (1): 249-255. DOI: 10.11646/ zootaxa.3752.1.15

Iturralde-Vinent M., Hubbell G., Rojas R. 1996. Catalogue ofCuban fossilElasmobranchii(PaleocenePliocene) and paleogeographic implications of their Lower-Middle Miocene occurrence. Boletín de la Sociedad Jamaicana de Geología 31: 7-21.

Long D.J., Sala E., Ballesteros E., Caselle J.E., Friedlander A.M., Klapfer A., Blum S., Constable H.B. 2014. Summary of South American records of the smalltooth sand tiger shark Odontaspis ferox (Chondrichthyes: Odontaspidae), with the first record from Chilean waters. Marine Biodiversity Records 7: e67. DOI: 10.1017/S1755267214000700

Marsili S. 2008. Systematic, paleoecologic and paleobiogeographic analysis of the Plio-Pleistocene Mediteranean elasmobranch fauna. Atti della Società toscana di scienze naturali; Memorie, Serie A 113: 81-88.

Marsili S. 2006. Analisi sistematica, paleoecologica e paleobiogeografica della selaciofauna plio-pleistocenica del Mediterraneo. Dottorato di ricerca in scienze della terra XIX Ciclo; dissertazione finale. Dipartimento di scienze della terra, Università di Pisa, Pisa, Italy.

Maul G. 1955. Five species of rare sharks new for Madeira including two new to science. Notulae Naturae 279: 1-13.

Meco J., Koppers A.A.P., Miggins D.P., Lomoschitz A., Betancort J.-F. 2015. The Canary record of the evolution of the North Atlantic Pliocene: $\mathrm{New}^{40} \mathrm{Ar} /{ }^{39} \mathrm{Ar}$ ages and some notable palaeontological evidence.
Palaeogeography, Palaeoclimatology, Palaeoecology 435: 53-69. DOI: 10.1016/j.palaeo.2015.05.027

Musick J.A., Ellis J.K. 2005. [Chapter 3] Reproductive evolution of chondrichthyans. Pp. 45-79. In: Hamlett W. (ed.) Reproductive biology and phylogeny of Chondrichthyes: Sharks, batoids and chimaeras. Vol. 3. CRC Press, Boca Raton, FL, USA.

Naylor G.J.P., Caira J.N., Jensen K., Rosana K.A.M., Straube N., Lakner C. 2012a. [2] Elasmobranch phylogeny: A mitochondrial estimate based on 595 species. Pp. 31-56. In: Carrier J.C., Musick J.A., Heithaus M.R. (eds.) The biology of sharks and their relatives. 2nd edn. CRC Press, Boca Raton, FL, USA.

Naylor G.J.P., Caira J.N., Jensen K., Rosana K.A.M., White W.T., Last P.R. 2012b. A DNA sequence-based approach to the identification of shark and ray species and its implications for global elasmobranch diversity and parasitology. Bulletin of the American Museum of Natural History 367: 1-262.

Portell R.W., Hubbel G., Donovan S.K., Green J.L., Harper D.A.T., Pickerill R. 2008. Miocene sharks in the Kendeace and Grand Bay formations of Carriacou, The Grenadines, Lesser Antilles. Caribbean Journal of Science 44 (3): 279-286. DOI: 10.18475/cjos.v44i3.a2

Purdy R.W., Schneider V.P., Applegate S.P., Mclellan J.H., Meyer R.L., Slaughter R. 2001. The Neogene sharks, rays, and bony fishes from Lee Creek Mine, Aurora, North Carolina. Pp. 71-202. In: Ray C.E., Bohaska D.J. (eds.) Geology and paleontology of the Lee Creek Mine, North Carolina III. Smithsonian Contributions to Paleobiology No. 90.

Porteiro F.M., Menezes G.M., Afonso P., Monteiro J.G., Santos R.S. 2010. Marine fish (Chondrichthyes, Actinopterygii). Pp. 325-345. In: Borges P.A.V., Costa A., Cunha R., Gabriel R., Gonçalves V., Martins A.F., Melo I., Parente M., Raposeiro P., Rodrigues P., Santos R.S., Silva L., Vieira P., Vieira V. (eds.) A list of the terrestrial and marine biota from the Azores. Principia Editora, Cascais, Portugal.

Risso A. 1810. Ichthyologie de Nice, ou histoire naturelle des poissons du département des Alpes Maritimes. Schoel, Paris.

Ritter E.K., Compagno L.J.V. 2013. First record of a smalltooth sandtiger shark, Odontaspis ferox, from the Galápagos Islands. Marine Biodiversity Records 6: e130. DOI: $10.1017 / \mathrm{S} 1755267213001115$

Rogan E., Mackey M. 2007. Megafauna bycatch in drift nets for albacore tuna (Thunnus alalunga) in the NE Atlantic. Fisheries Research 86 (1): 6-14. DOI: 10.1016/j.fishres.2007.02.013

Saïdi B., Bradaï M.N., Bouaïn A., Guélorget O., Capapé C. 2005. Capture of a pregnant female white shark, Charcharodon carcharias (Lamnidae) in the Gulf of Gabès (southern Tunisia, central Mediterranean) with comments on oophagy in sharks. Cybium 29 (3): 303307.

Santander-Neto J., Faria V.V., Castro A.L.F., Burgess G.H. 2011. New record of the rare ragged-tooth shark, 
Odontaspis ferox (Chondrichthyes: Odontaspidae) from the south-west Atlantic identified using DNA bar coding. Marine Biodiversity Records 4: e75. DOI: 10.1017/S1755267211000698

Santos R.S., Porteiro F.M., Barreiros J.P. 1997. Marine Fishes fo the Azores: Annotated checklist and bibliography: A catalogue of the Azorean marine ichthyodiversity. Arquipelago-Life Marine Sciences Suppl. 1. Universidade dos Açores, Horta, Portugal.

Serralheiro A.M.R. 1976. A geologia da Ilha de Santiago (Cabo Verde). [The Geology of the Island of Santiago (Cape Verde).] Boletim do Museu e Laboratório Mineralógico e Geológico da Faculdade de Ciências de Lisboa 14 (9): 157-372. [In Portuguese.]

Staig F., Hernández S., López P., Villafaña J.A., Varas, C., Soto L.P., Carrillo-Briceño J.D. 2015. Late Neogene elasmobranch fauna from the Coquimbo formation, Chile. Revista Brasileira de Paleontologia 18 (2): 261-272. DOI: 10.4072/rbp.2015.2.07
Suarez M.E., Encinas A., Ward D.J. 2006. An early Miocene elasmobranch fauna from the Navidad Formation, Central Chile, South America. Cainozoic Research 4 (1-2): 3-18.

Villavicencio-Garayzar C. 1996. The ragged-tooth shark, Odontaspis ferox (Risso, 1810), in the Gulf of California. California Fish and Game 82 (4): 195-196.

Wellington C.M., Wakefield C.B., White W.T. 2017. First record of Odontaspis ferox (Risso, 1810) in the temperate south-eastern Indian Ocean from in situ observations in a deep-water canyon using baited video. Journal of Applied Ichthyology 33 (1): 133135. DOI: $10.1111 /$ jai. 13190

Wirtz P., Brito A., Falcón J.M., Freitas R., Fricke R., Monteiro V., Reiner F., Tariche O. 2013. The coastal fishes of the Cape Verde Islands-New records and an annotated check-list: (Pisces). Spixiana 36 (1): 113-142.

Received: 21 May 2018

Accepted: 10 June 2018

Published electronically: 30 June 2018 